\title{
Correction to: OnabotulinumtoxinA in Chronic Migraine: A Profile of Its Use
}

\author{
James E. Frampton ${ }^{1}$
}

Published online: 21 May 2021

(c) Springer Nature Switzerland AG 2021

\section{Correction to: CNS Drugs (2020) 34:1287-1298 \\ https://doi.org/10.1007/s40263-020-00776-8}

After publication in CNS Drugs (2020) 34:1287-1298, a video abstract of the article was published on the Adis journals figshare page. The sentence in the 'Additional information' section of the HTML version of the article and in the article note at the bottom left of page 1287 of the PDF version that previously read:

Enhanced material for this Adis Drug Q\&A can be found at https://doi.org/10.6084/m9.figshare.13218869.

Should read:

Enhanced material for this Adis Drug Q\&A, including a video abstract, can be found at https://doi.org/10.6084/m9. figshare. 13218869 .

The original article can be found online at https://doi.org/10.1007/ s40263-020-00776-8.

James E. Frampton

demail@springer.com

1 Springer Nature, Private Bag 65901, Mairangi Bay, Auckland 0754, New Zealand 